\title{
İdiyopatik Bilateral Aksesuar Sinir Felci
}

\author{
Kadir Güler, Halil Öğüt*
}

DOI: $10.17944 /$ mkutfd.568632

Kadir Güler: Uzm. Dr., Mustafa Kemal Üniversitesi Tayfur Ata Sökmen Tip Fakültesi, Fiziksel Tıp ve

Rehabilitasyon Anabilim Dalı, Hatay

Email: drkadirguler@gmail.com

ORCID iD: https://orcid.org/0000-0001-9465-6665

Halil Öğüt: Uzm. Dr., Bingöl Devlet Hastanesi, Fiziksel Tıp ve Rehabilitasyon Kliniği, Bingöl Email: oguthalil@gmail.com

ORCID iD: https://orcid.org/0000-0002-0910-5728

Bildirimler/Acknowledgement

Yazarlar bu makale ile ilgili herhangi bir çıka çatıșması bildirmemișlerdir.

The authors declare that they have no conflict of interests regarding content of this article.

Yazarlar bu makale ile ilgili herhangi bir finansal destek bildirmemișlerdir.

The Authors report no financial support regarding content of this article.

Received: 21.05.2019

Accepted: 27.05.2019

e-ISSN: 2149-3103

Web: http://dergipark.gov.tr/mkutfd 0̈z

idiyopatik Bilateral Aksesuar Sinir Felci

Spinal aksesuar sinir hasarı sıklıkla boyun cerrahileri sonrasında görülmektedir. Cerrahi dıșında traksiyon, gerilme, künt travma, penetran yaralanmalar gibi çeşitli nedenlerle izole spinal aksesuar sinir hasarı görülmektedir. Spinal aksesuar sinir felcinde trapez kas atrofisi, servikal dismetri, omuzda çökme, supraspinatus çıkıșında daralma sonucu subakromiyal sıkıșma görülebilir. Bu yazıda omuz ağrısı ve güçsüzlük ile bașvuran hastada bilateral spinal aksesuar sinir felci gelişimini sunmayı amaçladık.

Anahtar Kelimeler: Aksesuar sinir, 0muz ağrısı, Sinir felci

\section{Abstract}

Idiopathic Bilateral Accessory Nerve Palsy

Spinal accessory nerve injury is often seen after neck surgeries. Isolated spinal accessory nerve injury is observed for various reasons such as traction, stretching, blunt trauma, and penetrating injuries. In spinal accessory nerve palsy, there may be trapezoidal muscle atrophy, cervical dysmetria, collapse in the shoulder, and contraction of supraspinatus. In this article, we aimed to present the development of bilateral spinal accessory nerve palsy in the patient presenting with shoulder pain and weakness.

Keywords: Accessory nerve, shoulder pain, nerve palsy

\section{GİRIŞ}

Spinal aksesuar sinir hasarı sıklıkla boyun cerrahileri sonrasında görülmektedir. Cerrahi dışında traksiyon, gerilme, künt travma, penetran yaralanmalar gibi çeşitli nedenlerle izole spinal aksesuar sinir hasarı görülmektedir $(1,2)$. İdiyopatik brakiyal pleksopati veya amyotrofi olarak da adlandirılan Parsonage - Turner sendromunda sıklıkla omuz ağrısı ve güçsüzlük görülmektedir (3). Aksesuar sinir hasarlanmalarının \%71'nin iatrojenik, \%24'nün travmalarla ilişkili olduğu bulunmuştur. İdiyopatik veya spontan olarak görülme oranı ise oldukça düşüktür (4).

Spinal aksesuar sinir juguler foremenden çıktıktan sonra, önce sternokloidomastoid kasını sonra trapez kasını uyarır. Klinik olarak sıklıkla trapezius kasındaki kuvvetsizlik, omuzlarda düşme ve skapulanın aşağı ve dışa rotasyonuyla kanat skapulaya yol açar. Bununla beraber omuz ağrısı eşlik edebilmektedir.

\section{OLGU SUNUMU}

19 yaşında erkek hasta, yaklaşık üç ay önce sağ omuzda başlayan ağrı ve bir aydır her iki kolunu kaldırmakta güçlük şikâyeti ile fizik tedavi polikliniğine başvurdu. Tarafımıza başvurmadan yaklaşık 2 ay önce dış merkezde ortopedi polikliniğine sağ omuz ağrısı şikayetiyle başvurmuş. O dönemde çekilen sağ omuz MR görüntülemesi subdeltoit bursit olarak raporlanmış. Öyküsünde yaklaşık 3 ay öncesine kadar fitnes ve ağırlık çalışmak dışında özellik yoktu. Ek bir hastalığı yoktu. Travma ve geçirilmiş cerrahi öyküsü yoktu. Fizik muayenesinde, bilateral üst trapezde atrofi ve omuzlarda çökme ve kanat skapula mevcuttu. Özellikle sağ omuzda olmak üzere bilateral aktif elevasyonda kısıtlılık mevcuttu. Bilateral omuz abduksiyonu 4-/5, fleksiyonu 4/5, iç rotasyon, diş rotasyon, adduksiyon ve ekstansiyon kas güçleri 5/5 olarak değerlendirildi. Servikal kas kuvvetleri her yöne global olarak 5/5'di. Derin tendon refleksleri 
normoaktifti ve patolojik refleksler negatifti. Yapılan hemogram ve biyokimya tetkiklerinde özellik yoktu. Hastaya "aksesuar sinir arazı" ön tanısıyla elektromiyografi istendi. Bulgular bilateral spinal aksesuar sinir aksonal hasarı ile uyumlu olarak raporlandı. Etiyoloji araștırmak amacıyla hastadan servikal ve kranial MR görümtülemesi yapıldı, sonuçlar normal olarak raporlandı. Hasta bu şikayetlerle rehabilitasyon programına alındı. Bilateral trapez kasına 15 seans $20 \mathrm{dk}$ elektrik stimülasyonu uyguland. Eklem hareket açıklı̆̆ egzersizleri ve tüm yönlerde izometrik güçlendirme egzersizleri $30 \mathrm{dk}$ çalıştırıldı. Tedavi sonrası trapez güçlendirme için ev egzersiz programı düzenlendi. İki ay sonraki kontrolde hastanın bilateral omuz aktif eklem hareketleri normal sınırlar içerisindeydi, omuz elevasyon kas gücü 4+/5 olarak değerlendirildi.

\section{TARTIŞMA}

Spinal aksesuar sinir felcinde trapez kas atrofisi, servikal dismetri, omuzda çökme, supraspinatus çıkışında daralma sonucu subakromiyal sıkışma görülebilir. Omuz elevasyonunda güçsüzlük ortaya çıkar. Bunun yanında skapulada kanatlanma meydana gelir(5). Bizim vakamızda hastamızın ilk şikâyeti ağrı olmuştur. Bu şikayetle dış merkezde yapılan değerlendirmelerde sıkışma sendromu olarak değerlendirilmiştir. Hasta yaklaşık 2 ay sonra tarafımızca değerlendirildiğinde ağrı şikayetinin yanında hareket kısıtlılığı şikâyeti de mevcuttu. İnspeksiyon, palpasyon ve kas gücü değerlendirildiğinde hastanın bilateral trapez kasının atrofik olduğu saptandı. Ayrıca kanat skapula da eșlik etmekteydi. Vakamızda öncelikli semptom ağrı olmuştur. Daha sonra hareket kısıtlılığı eklenmiştir. Subakromiyal sıkışma sendromu ile başvuran hastalarda ağrı nedeniyle kas gücü değerlendirmesi göz ardı edilebilmektedir. Fakat omuz kuşağı kaslarındaki güçsüzlüğünde sıkışma sendro- muna sebep olabileceği unutulmamalıdır. Omuz ağrısı ile başvuran hastalarda eğer mümkünse mutlaka kas gücü değerlendirilmesi yapılmalıdır.

Literatür tarandığında idiopatik spinal aksesuar sinir hasarlanması olan vakalar bildirilmiștir (6). Literatürde iatrojenik bilateral aksesuar felci bildiren vakalar mevcutken, idiopatik bilateral spinal aksesuar sinir hasarlanması bildiren yayın yoktur (7). Vakamız etyolojisinde literatürle uyumlu herhangi bir neden bulunmayan ve bilateral spinal aksesuar sinir hasarı görülen ilk vaka olması nedeniyle kyymetlidir.

\section{KAYNAKLAR}

1. Aksoy IA, Schrader SL, Ali MS, Borovansky JA, Ross MA. Spinal accessory neuropathy associated with deep tissue massage: a case report. Archives of physical medicine and rehabilitation. 2009;90(11):1969-72.

2. Bodack MP, Tunkel RS, Marini SG, Nagler W. Spinal accessory nerve palsy as a cause of pain after whiplash injury: case report. Journal of pain and symptom management. 1998;15(5):321-8.

3. Wills AJ, Sawle GV. Accessory nerve palsies. Practical neurology. 2010;10(4):191-4.

4. Donner TR, Kline DG. Extracranial spinal accessory nerve injury. Neurosurgery. 1993;32(6):907-11.

5. Martin SC, Thornhill TS. Omuz Ağrısı. In: Harris ED, Budd RC, GS Firestein, editors. Kelley Romatoloji 12006. p. 557-87.

6. Gürsoy Azize E, Babacan-Yildiz G, Kolukisa M, Celebi A. Idiopathic spinal accessory nerve palsy: A case report and review of the literature. Neurology India. 2013;61(1).

7. Gale GL. Bilateral Accessory Nerve Paralysis. Canadian Medical Association journal. 1954;70(2):191. 